\title{
Penentuan Koefisien Momen Inersia Benda Tegar Berbasis Arduino
}

\author{
Rustan $^{* 1}$, Linda handayani ${ }^{2}$ \\ ${ }^{1}$ Program Studi Fisika, Fakultas Sains dan Teknologi, Universitas Jambi \\ e-mail: *1 1 rustan.rustan@ unja.ac.id, ${ }^{2}$ linda.excellent@gmail.com
}

\begin{abstract}
Abstrak
Pada penelitian ini telah dilakukan penentuan koefisien momen inersia menggunakan bantuan mikrokontroller Arduino Uno sebagai alternatif penyelesaian yang lebih mudah. Benda yang menjadi objek pada penelitian ini yaitu bola berongga (bola basket) dan silinder berongga (pipa paralon) yang secara teori memiliki koefisien momen inersia berturut-turut sebesar 0.67 dan 1. Percobaan dilakukan dengan menggelindingkan objek pada bidang miring yang ketinggiannya dapat diubah-ubah. Dua buah sensor fotodioda yang terhubung dengan mikrokontroler arduino uno dipasang pada puncak bidang miring dan dasar bidang miring dengan jarak tertentu untuk mengukur kecepatan benda saat sampai di dasar bidang miring. Data-data yang didapatkan selanjutnya diplot pada grafik hubungan kecepatan kuadrat $\left(v^{2}\right)$ terhadap ketinggian bidang miring $(h)$. Hasil pengolahan dan analisa data didapatkan koefisien momen inersia bola berongga sebesar 0.68 dengan error $1.49 \%$ dan koefisien momen inersia silinder berongga sebesar 0.98 dengan error $2 \%$.
\end{abstract}

Kata kunci : Arduino Uno, Benda Tegar, Momen Inersia

\section{PENDAHULUAN}

Benda yang bergerak berputar (rotasi dan menggelinding) dapat dengan mudah ditemukan dalam kehidupan sehari-hari, seperti gerakan roda kendaraan, komedi putar, putaran baling-baling pesawat, dan mainan yoyo. Benda yang berputar memiliki beberapa besaran yang tidak dimiliki oleh benda yang bergerak lurus (translasi), salah satunya adalah momen inersia. Momen inersia merupakan kecenderungan suatu benda untuk mempertahankan kecepatan sudutnya, identik dengan massa pada gerak translasi. Nilai momen inersia benda tegar bervariasi bergantung pada bentuk benda dan sumbu putar benda. Perbedaan nilai momen inersia setiap benda dikarakterisasi melalui suatu bilangan yang disebut koefisien momen inersia $(k)$. Benda yang memiliki bentuk yang sama belum tentu memiliki koefisien momen inersia yang sama jika sumbu putarnya berbeda.

$I=k m r^{2}$

Berikut koefisien momen inersia beberapa benda tegar dengan sumbu putar sejajar sumbu utama (Giancoli, 2001):

Tabel 1. Koefisien Momen Inersia (k) beberapa benda

\begin{tabular}{|l|c|}
\hline \multicolumn{1}{|c|}{ Benda } & Koefisien Momen Inersia $(\mathrm{k})$ \\
\hline Bola Pejal & 0.4 \\
\hline Bola Berongga & 0.67 \\
\hline Silinder Pejal & 0.5 \\
\hline Silinder Berongga & 1 \\
\hline
\end{tabular}


Penentuan nilai $k$ dapat dilakukan dengan menggunakan kalkulus melalui metode integral, akan tetapi cukup sulit dilakukan meskipun pada benda-benda yang bentuknya teratur dan homogen (Abdullah, 2016). Sebagai alternatif penyelesaian yang lebih mudah dipahami oleh peserta didik, Riswanto (2014), Cahyadi et.al (2015), dan Yusuf (2015) mencoba menentukan koefisien momen inersia menggunakan Video Based Laboratory (VBL) dan Software Tracker. Hasil yang diperoleh cukup akurat, akan tetapi hasil sangat bergantung pada kualitas kamera digital yang digunakan. Berdasarkan hal tersebut, penulis ingin mencoba menentukan koefisien momen inersia dengan pendekatan yang lain yaitu instrumen berbasis Arduino menggunakan sensor fotodioda. Ketika benda bergerak melewati fotodioda dan menghalangi sinar sumber, maka photodioda akan memberikan sinyal aktif ke arduino melalui jalur interupsi sebagai nilai awal, demikian pula ketika objek melewati photodioda kedua yang disimpan sebagai nilai akhir. Pembagian antara jarak sensor dengan waktu ini akan diperoleh kecepatan. Penentuan kecepatan benda sebenarnya bisa dilakukan dengan menghitung dengan formula menggunakan waktu yang diukur menggunakan stopwatch. Dengan menggunakan sensor akan mengurangi kesalahan pengukuran yang disebabkan faktor human error (Setiorini, 2014).

Tinjau sebuah benda tegar yang menggelinding pada suatu bidang miring dengan ketinggian tertentu:

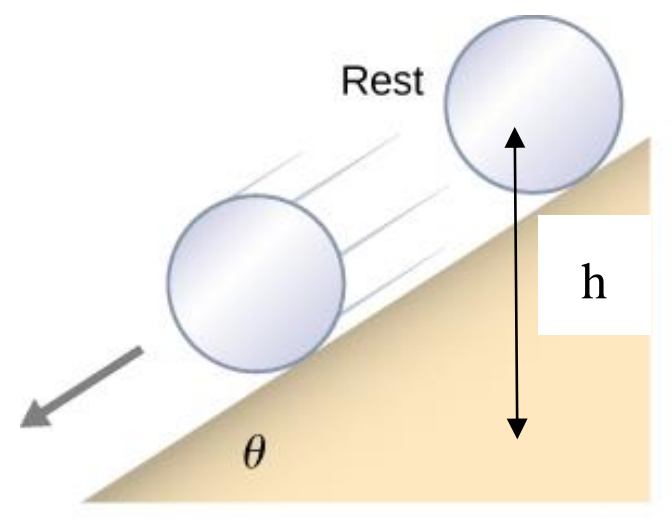

Gambar 1. Gerak Menggelinding Benda Tegar pada Bidang Miring

Dengan menggunakan hukum kekekalan energi mekanik pada benda yang menggelinding, akan diperoleh formula kecepatan sebagai fungsi dari ketinggian:

$$
\begin{aligned}
\left(E_{k_{-} \text {translasi }}+E_{k_{-} \text {rotasi }}+E_{p}\right)_{\text {puncak }} & =\left(E_{k_{-} \text {translasi }}+E_{k_{-} \text {rotasi }}+E_{p}\right)_{\text {dasar }} \\
0+0+m g h & =\frac{1}{2} m v^{2}+\frac{1}{2} I \omega^{2}+0 \\
m g h & =\frac{1}{2} m v^{2}+\frac{1}{2}\left(k m r^{2}\right) \frac{v^{2}}{r^{2}} \\
g h & =\frac{1}{2} v^{2}+\frac{k}{2} v^{2} \\
g h & =\left(\frac{k+1}{2}\right) v^{2} \\
v^{2} & =\frac{2 g h}{k+1} \\
v^{2} & =\left(\frac{2 g}{k+1}\right) h
\end{aligned}
$$

Dengan kemiringan $m=\frac{2 g}{k+1}$ 
Formula (2) merupakan formula grafik hubungan antara ketinggian bidang miring $(h)$ terhadap kecepatan kuadrat $\left(v^{2}\right)$. Jika kemiringan grafik $(m)$ tersebut diketahui, maka nilai koefisien momen inersia $(k)$ dapat ditentukan

\section{METODE PENELITIAN}

\subsection{Alat dan Bahan}

1. Mikrokontroller Arduino Uno, 1 buah

2. LCD, 1 buah

3. Sensor fotodioda, 2 buah

4. LED, 2 buah

5. Papan Bidang Miring, 1 buah

6. Bola Berongga (Bola Basket)

7. Silinder Berongga (Pipa Paralon)

8. Meteran

\subsection{Prosedur Pelaksanaan}

Penelitian ini dilakukan dengan mengikuti langkah-langkah sebagai berikut:

1. Memasang dua sensor fotodioda pada bidang miring pada jarak 3 meter.

2. Mengatur ketinggian bidang miring $10 \mathrm{~cm}$.

3. Menggelindingkan bola berongga (bola basket) pada bidang miring melewati sensor.

4. Mencatat nilai kecepatan benda yang tampil di layar.

5. Mengulangi langkah $1-4$ untuk ketinggian bidang miring $20 \mathrm{~cm}, 30 \mathrm{~cm}, 40 \mathrm{~cm}$, dan $50 \mathrm{~cm}$.

6. Mengulangi langkah $3-5$ untuk untuk silinder berongga (pipa paralon).

\subsection{Analisis Data}

1. Membuat tabel yang membuat data ketinggian $(h)$, kecepatan $(v)$, dan kecepatan kuadrat $\left(v^{2}\right)$ pada bola pejal (bola basket).

2. Membuat grafik hubungan ketinggian $(h)$ di sumbu $\mathrm{x}$ dan kecepatan kuadrat $\left(v^{2}\right)$ di sumbu $\mathrm{y}$ menggunakan Microsoft Excel.

3. Menentukan nilai gradien garis hasil plot grafik.

4. Setelah nilai gradien diperoleh, selanjutnya menentukan perhitungan nilai koefisien momen inersia menggunakan formula yang telah didapatkan.

5. Melakukan analisi data yang sama pada silinder berongga (pipa paralon)

\section{HASIL DAN PEMBAHASAN}

Pada penelitian ini tiap objek digelindingkan pada bidang miring yang ketinggiannnya dapat diubahubah yaitu sebesar $10 \mathrm{~cm}, 20 \mathrm{~cm}, 30 \mathrm{~cm}, 40 \mathrm{~cm}$, dan $50 \mathrm{~cm}$. Pembacaan nilai kecepatan benda hasil pengukuran sensor saat benda sampai di dasar bidang miring ditampilkan dalam LCD. Nilai kecepatan semakin besar apabila ketinggian bidang miring diperbesar. Secara lengkap disajikan dalam tabel berikut:

Tabel 2. Data ketinggian bidang miring dan kecepatan bola berongga

\begin{tabular}{|c|c|c|}
\hline Ketinggian $(\mathrm{m})$ & Kecepatan $(\mathrm{m} / \mathrm{s})$ & Kecepatan kuadrat $\left(\mathrm{m}^{2} / \mathrm{s}^{2}\right)$ \\
\hline 0,1 & 1,06 & 1,13 \\
\hline 0,2 & 1,54 & 2,36 \\
\hline 0,3 & 1,88 & 3,55 \\
\hline
\end{tabular}


https://jurnal.unsulbar.ac.id/index.php/saintifik

\begin{tabular}{|l|l|l|}
\hline 0,4 & 2,18 & 4,74 \\
\hline 0,5 & 2,40 & 5,78 \\
\hline
\end{tabular}

Tabel 3. Data ketinggian bidang miring dan kecepatan silinder berongga

\begin{tabular}{|c|c|c|}
\hline Ketinggian $(\mathrm{m})$ & Kecepatan $(\mathrm{m} / \mathrm{s})$ & Kecepatan kuadrat $\left(\mathrm{m}^{2} / \mathrm{s}^{2}\right)$ \\
\hline 0,1 & 0,95 & 0,91 \\
\hline 0,2 & 1,33 & 1,76 \\
\hline 0,3 & 1,66 & 2,74 \\
\hline 0,4 & 1,96 & 3,86 \\
\hline 0,5 & 2,19 & 4,81 \\
\hline
\end{tabular}

Dari data di atas, di peroleh grafik hubungan sebagai berikut:

Hubungan Ketinggian Bidang Miring dengan Kecepatan Kuadrat

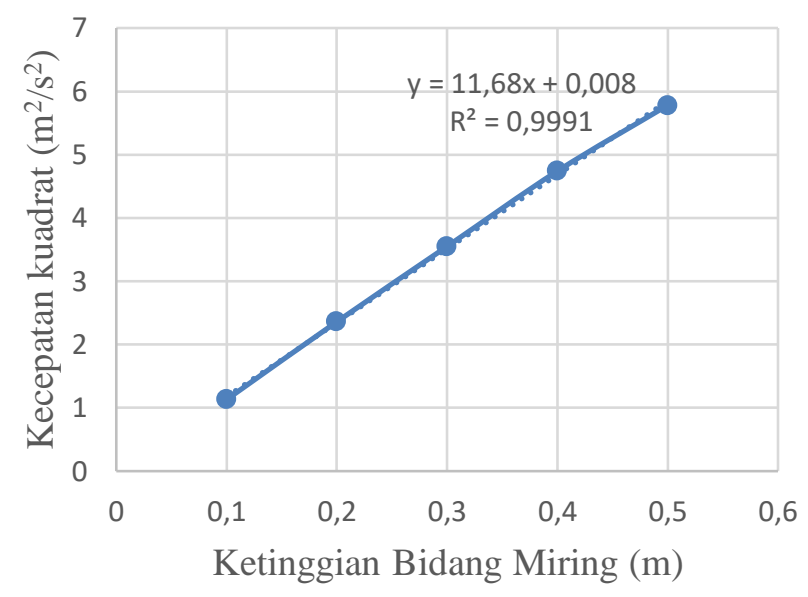

Gambar 2. Grafik Ketinggian bidang miring terhadap kecepatan kuadrat

Hubungan Ketinggian Bidang Miring dengan Kecepatan Kuadrat

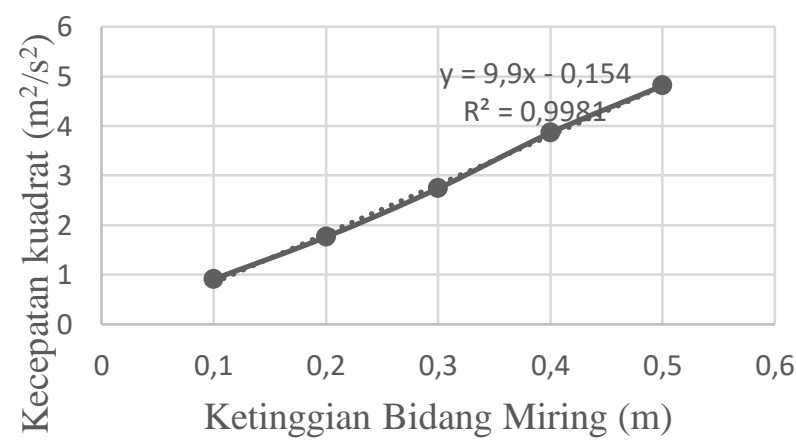

Gambar 3. Grafik Ketinggian bidang miring terhadap kecepatan kuadrat 
https://jurnal.unsulbar.ac.id/index.php/saintifik

Hubungan antara ketinggian bidang miring $(h)$ dengan kecepatan kuadrat $\left(v^{2}\right)$ yaitu berbanding lurus membentuk garis lurus dengan kemiringan tertentu. Dengan bantuan microsoft excel, didapatkan dengan mudah garis linier sehingga dapat ditentukan nilai kemiringan garis tersebut.

Dengan menggunakan formula (3) maka diperoleh koefisien momen inersia $(k)$ :

Tabel 4. Koefisien momen inersia $(k)$ Hasil Penelitian

\begin{tabular}{|c|c|c|c|}
\hline Benda & k terukur & $\mathrm{k}$ teori & Error \\
\hline Bola Berongga & 0,68 & 0,67 & $1,49 \%$ \\
\hline Silinder Berongga & 0,98 & 1 & $2,00 \%$ \\
\hline
\end{tabular}

\section{KESIMPULAN}

Penentuan koefisien momen inersia benda tegar dapat dilakukan dengan bantuan perangkat mikrokontroler arduino uno dengan hasil yang cukup akurat, dengan kesalahan dibawah 5\%. Selain itu metode ini cukup sederhana dan mudah dilakukan sehingga dapat membantu peserta didik pada sekolah menengah untuk menentukan koefisien momen inersia. Sebagai saran penelitian selanjutnya, dapat dilakukan eksperimen untuk menentukan koefisien momen inersia benda tegar yang tidak bisa menggelinding seperti benda berbentuk batang dan balok.

\section{DAFTAR PUSTAKA}

Cahyadi, M. dkk. 2015. Penentuan Koefisien Momen Inersia Benda Tegar dengan Pendekatan Dinamik Menggunakan Pemrosesan dan Analisis Video Digital. Prosiding Simposium Nasional Inovasi dan Pembelajaran Sains (SNIPS), Bandung. ISBN: 978-602-19655-8-0, hlm. 121 - 124.

Giancoli, Douglas C. 2001. Fisika Jilid 1. Edisi kelima. Penerbit Erlangga, Jakarta.

Mikrajuddin, Abdullah. 2016. Fisika Dasar 1. Institut Teknologi Bandung: Bandung.

Riswanto dan Suharno. 2014. Penentuan Koefisien Momen Inersia Bola Pejal Melalui Video Gerak pada Bidang Miring dengan Fitting Data. Prosiding Pertemuan Ilmiah XXVIII HFI Jateng\&DIY. ISSN: 08530823, hlm. $31-34$.

Setiorini, Indah. 2014. Rancang Bangun Smart Timer sebagai Alat Pengukur Waktu dan Kecepatan untuk Media Pembelajaran Gerak Lurus. Jurnal Fisika, 02, 53 - 59.

Yusuf, Kholid. 2015. Penentuan Koefisien Momen Inersia dengan Video Analisis. Prosiding Seminar Nasional Fisika dan Pendidikan Fisika Ke-6. Volume 6 Nomor 1.ISSN:2302-7827, hlm. 174 - 178. 